\title{
USING NON-DESTRUCTIVE TESTS FOR EVALUATING FLYOVER FOOTBRIDGE: CASE STUDY
}

\author{
Ali Abdulhussein Shubbar ${ }^{1, *}$, Zainab S. Al-khafaji ${ }^{2}$, Mohammed Salah Nasr ${ }^{3}$, Mayadah W. Falah ${ }^{4}$ \\ ${ }^{1}$ Department of Civil Engineering, Liverpool John Moores University, Henry Cotton Building, Webster Street, \\ Liverpool, L3 2ET, UK. \\ ${ }^{2}$ Al-Furrat Al-Awsat Distribution Foundation, Ministry of Oil, Babylon, Iraq. \\ ${ }^{3}$ Babylon Technical Institute, Al-Furat Al-Awsat Technical University, 51015, Babylon, Iraq. \\ ${ }^{4}$ Department of Civil Engineering, Al-Mustaqbal University College, Hillah, Iraq. \\ *Corresponding: a.a.shubbar@2014.ljmu.ac.uk, alishubbar993@gmail.com
}

\begin{abstract}
The concrete structures deterioration in the last few decades required effective methods for evaluating and maintaining the structure condition. Currently, assessing the performance and safety of reinforced concrete (RC) structures relies on routine-based visual inspection (VI). However, there are another non-destructive test (NDT) technique that can provide a more accurate assessment of the structures. Thus, in this study, a footbridge located in Liverpool, UK is chosen as a case study and has NDT techniques used for assessment. The main objective of this research is to determine the condition of structural bridge components and investigate its level of defect and deterioration using non-destructive tests. The methodologies involved are visual inspection, and NDT techniques include the rebound hammer, cover meter, Moisture Content \& Depth of Carbonation Testing, Chloride Testing and Half Cell Test. The framework, when implemented with the best selection of NDT techniques, helps in determining the level of defect and deterioration of the structural bridge components and next recommendation regarding the condition of the bridge. The involved bridge structural components include column, deck, wall and staircase. Findings from the visual inspection show that there were many defects and deteriorations found at the structural bridge components, which includes crack, spalling, and delamination and rusting. Further, NDT techniques that were carried out at the selected bridge structural part shows that some of the components exhibited a moderate risk of corrosion and acceptable concrete surface quality. In general, further maintenance is needed specifically to some critical structural components of the bridge.
\end{abstract}

Keywords: Cover meter; chloride testing; footbridge; flyover; rebound hammer; moisture Content.

\section{Introduction}

Over time, bridges and structures deteriorate and require maintenance, replacement or rehabilitation. However, there is a need for cost-effective methods and strategies that can accomplish that. European countries, particularly those located in the midland, have a high degree of humidity, which increases the risk of corrosion. The United Kingdom, in particular, has a high degree of humidity, particularly in the Western regions. Thus, structures routine inspection is needed to ensure that corrosion is not spearing or progressing to a degree in which it can't be controlled anymore.

In many cases, visual inspecting is not enough to reveal the corrosion rate. Thus, in addition to a visual inspection, other none destructive tests are required to indicate other problems that the structure might be facing [1]-[3]. Concrete degradation, steel corrosion, and weakening of connections in structures over time are significant concerns in crossing pedestrian bridges. If bridges are not maintained, and the damage is ignored, then over time the bridge will deteriorate. Thus, bridges are required to be constantly monitored and assessed [4].

Corrosion of steel reinforcement is the primary type of deterioration in concrete structures. It is one of the worst kinds of deterioration in concrete structures, and sometimes it results in cracking and causes severe damages to structures. Other dangerous deterioration processes that do severe damages to concrete structures include alkali-silica reactions and damages caused by freeze-thaw processes [5]-[7]. The electrochemical corrosion processes around a corrosion pit on steel in concrete are illustrated, and the electrochemical reactions can be summarized as process depicted below. The first three lines are the process in which the corrosion reacts, in the last line, the rust reaction occurs [8].

$$
\begin{gathered}
\mathrm{Fe} \leftrightarrow 2 \mathrm{e}^{-}+\mathrm{Fe}^{2+} \\
1 / 2 \mathrm{O}_{2}+\mathrm{H}_{2} \mathrm{O}+2 \mathrm{e}^{-} \leftrightarrow 2(\mathrm{OH})^{-}
\end{gathered}
$$




$$
\begin{gathered}
\mathrm{Fe}^{2+}+2(\mathrm{OH})^{-} \rightarrow \mathrm{Fe}(\mathrm{OH})_{2} \\
4 \mathrm{Fe}(\mathrm{OH})_{2}+2 \mathrm{H}_{2} \mathrm{O}+\mathrm{O}_{2} \rightarrow 4 \mathrm{Fe}(\mathrm{OH})_{3}
\end{gathered}
$$

Even though concrete has become a popular material for construction and building, it has some very core practical limitations such as its lack of flexibility and deformation. They are using steel as a reinforcement agent where tensile stresses are located. However, this creates a challenge not only related to embed these materials into concrete but also related to the process of reacting with others. These two materials are relatively compatible in most areas, mainly because they share the same thermal expansion coefficient. There are also corrosion control methods that can be used that can prolong the duration at which the metal and electrolytes interact, slowing down the rate of corrosion considerably [9].

There are significant advances in non-destructive electrochemical techniques for the measurement of corrosion rates of reinforcement embedded in concrete. An inspection of a bridge, which involves a systematic check on the physical condition of a bridge, is effective in preventing any undesirable incident such as failure from happening. This involves early detection and recommendations of any problems that may arise from propagating to a critical condition. Another motivation for bridge inspection is in the preservation of capital investment, as maintaining a bridge, is much cheaper than rebuilding one. Proper monitoring solution can ultimately lead to reduced costs over time. Hence, focusing on assessing the condition of structures and bridges effective can lead to the preservation of time and resources.

Non- destructive testing (NDT) is a way of testing concrete in situ without detrimentally damaging. These tests comprise of many different methods to gather information about different aspects of the concrete in the structure that might be damaged or weakened. There are significant advances in non-destructive electrochemical techniques for the measurement of corrosion rates of reinforcement embedded in concrete. An inspection of a bridge, which involves a systematic check on the physical condition of a bridge, is effective in preventing any undesirable incident such as failure from happening. This involves early detection and recommendations of any problems that may arise from propagating to a critical condition. Another motivation for bridge inspection is in the preservation of capital investment, as maintaining a bridge, is much cheaper than rebuilding one. Proper monitoring solution can ultimately lead to reduced costs over time. Hence, focusing on assessing the condition of structures and bridges effective can lead to the preservation of time and resources [10].

The current research paper aims to investigate the current flyover bridge condition, to present a justification for the Liverpool city council if the bridge could be still working after miner maintenance or they should start the demolishing work.

\section{The selected Structure}

The Churchill Way flyover, Liverpool. This structure was completed and accessible to the public in 1969 as a part of the 2.4 million pound scheme 'Mersey Tunnel relief scheme'. This concrete structure is a winner of the Concrete Society Award, awarded in 1971 for being "elegant and efficient" [11] as shown in Figure 1.
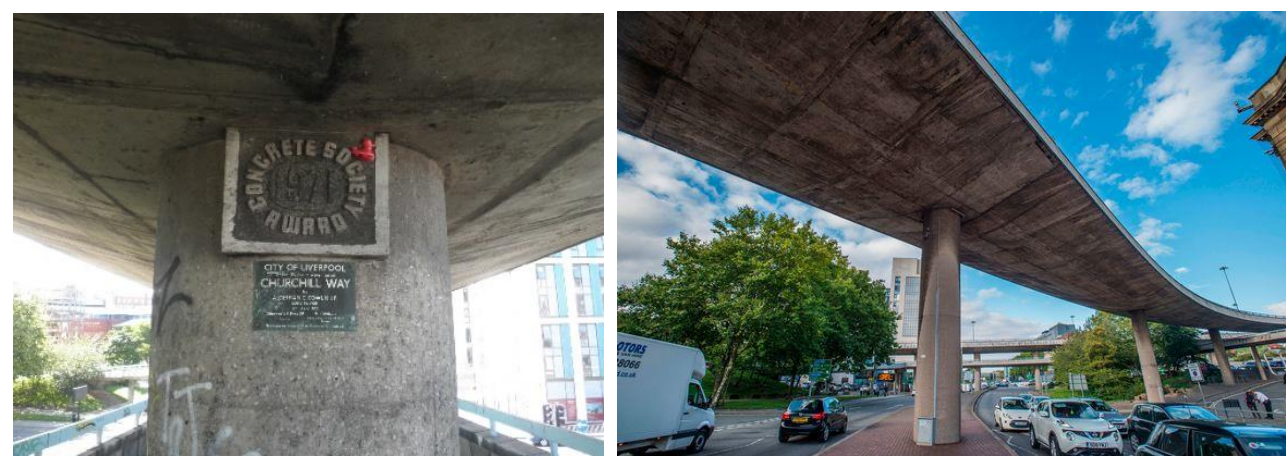

Figure 1: Churchill Way flyover, Liverpool, UK.

When looking at the history of the structure, an indicator might be the period it was built in the late 1960s were a time of great, rapid advancement. Concrete was frequently designed without true knowledge of exposure classes factored in, for example, Calcium chloride was used in structures, and this was later found to be detrimental to durability, discussed in depth in the report. Therefore, the structure has maintained in the supporting areas of the flyover concrete columns and the road on top. This gave an immediate direction to why the degradation may have occurred: chemical attack and carbonation; therefore, the NDTs that might be most useful in providing a complete image of the condition [12]. Figure 2 shows an issue in waterproofing under the flyover suggests there could be underlying issues with the structure. Furthermore, in the 1980s, the structure closed for three years for $£ 0.5$ million repairs, repairs that take three years, indicating that they were major repairs [11]. 

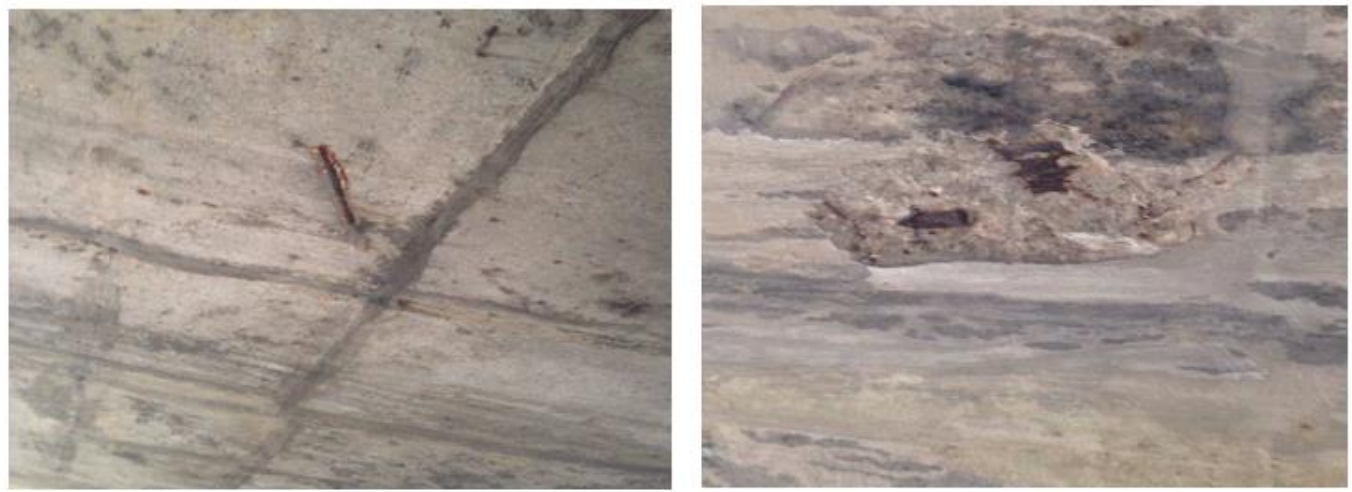

Figure 2: The underside of the Churchill Way flyover, rust coloured stain marks.

\section{Non-destructive}

This report investigates the condition of the structure, including a proposal of remedial works to maintain the structure. This investigation has been carried out with five different non-destructive testing's and link the different investigation techniques together. The NDT's used in this study include:

$\begin{aligned} \text { i. } & \text { Schmitt Hammer Test } \\ \text { ii. } & \text { Moisture Content \& Depth of Carbonation Testing } \\ \text { iii. } & \text { Chloride Testing } \\ \text { iv. } & \text { Cover Meter Test } \\ \text { v. } & \text { Half Cell Test }\end{aligned}$

\subsection{Schmidt Hammer (N) Test}

A Schmidt Hammer is used to investigate the compressive strength of in-place concrete, the uniformity of the concrete and indicate possible areas of deterioration. $\mathrm{N}$-type is used for materials with strength between $(10$ and 70) MPa, therefore, was used for the concrete load-bearing columns. This test will not damage the structure in any way an immediate result can be given. The device converts the average of the 8 -rebound values taken for an area into compressive strength (MPa). Therefore, this test is good at identifying a problem exists within the concrete but does not give a cause of the degradation that can be potentially overloading impact, chemical attack or contrarily poor initial construction [13].

\subsection{Moisture Content \& Depth of Carbonation Testing}

Concrete has a passive protective layer that is a structure's main line of defense against corrosion to any steel reinforcement. As the carbon dioxide reacts with calcium hydroxide that exists in concrete mixtures, it turns into calcium carbonate and water (Association, Portland Cement, 2002). This solution is acidic and causes a decrease in the alkalinity, thus reducing the passivation of the concrete. The natural $\mathrm{pH}$ of concrete is about 13 , and once these reactions have reduced the $\mathrm{pH}$ levels in the concrete to 9, it is considered de-passivized. Areas of de-passivation are considered not to be offering protection to the steel reinforcement [14], [15]. The reaction of corrosion takes place [16].

$$
\mathrm{Ca}(\mathrm{OH}) 2+\mathrm{CO}_{2} \rightarrow \mathrm{CaCO}_{3}+\mathrm{H} 2 \mathrm{O}
$$

The moisture content in the concrete mix is important due to higher water to cement ratio being cheaper but reduces the durability and increases the porosity of the cement allowing a chemical attack to occur at a faster rate. The strength at the highest values of water content in the cement mixtures can also detrimentally affect the strength of the concrete [17]. Besides, if the structure is more porous, it is also less dense. This has an immediate effect on the Schmidt hammer results. Carbonation has previously been talked about with regards to the Schmidt hammer. A less dense structure will not have the same capacity as one that is denser. The moisture content test consisted of two parts: a destructive moisture test to find different the moisture levels at differing depths in the blocks using the speedy moisture test and the next to find the moisture readings on the surface of the concrete sides using the quick moisture test. Although it is relatively non-destructive, however, it requires dust samples to find a value for the moisture content. Samples can be taken at different depths to produce a profile of moisture permeation through the structure. The samples are mixed with calcium carbide inside of a pressure gauge; the level of gas produced within the vessel can then be read as a percentage of the wet weight of the sample.

The depth for carbonation test was carried out on a block exposed to an urban environment in a storage bay. It would be tested on three different axes to find the 'carbonation front' where carbonation stopped occurring. An alcoholic solution of phenolphthalein that will indicate if the $\mathrm{PH}$ is over 9 to show where carbonation has not occurred, it will then turn a bold pink. The speedy moisture meter cannot give a determinate 
value for the moisture present throughout a concrete element. It will only measure the percentage of moisture found in the sample [10]. As the samples are only taken from shallow depths to minimize the damage to the structure, the moisture content of the surface sample can vary greatly from the internal moisture content due to weather exposure. The pore water in the concrete near the outer surface will cause an issue for durability in the winter months (the situation for the Churchill Way flyover) as the water in the pores expands when frozen and can create surface cracks, called freeze-thaw combined with other forms of degradation can cause the concrete to deteriorate faster than expected due to carbonation and chloride attack.

\subsection{Depth of carbonation}

The depth of carbonation was tested by drilling into a concrete block at different depths. All samples were sprayed with phenolphthalein, and then each face of the block was broken and sprayed. If the concrete colour changed to pink when sprayed, then carbonation was not present in the concrete. The concrete block with dimensions ( $410 \times 210 \times 95)$ was used in the test, as shown in Figure 3; the block got broken had not been contaminated by carbonation. Figure 4 shows un-carbonation, and Figure $4 \mathrm{~b}$ shows carbonation. The block then got chipped away at each face, but there was only one side was the block had no carbonation present [18]:

Depth of carbonation $(\mathrm{mm})=\sqrt{\text { Age (Year) }}$

Peneder et al. [18] state that this is a minima value for the speed of carbonation in an area where the conditions allow it. There are other factors that this equation does not take into account like the density of concrete, porosity and the volume of voids that all have a big bearing in the real world to how fast carbonation occurs. The minimum value that carbonation in the Churchill Way flyover has occurred considering it is 47 years old is about $6.9 \mathrm{~mm}$ but is most likely much higher; this, however, is ok if the level cover exceeds the carbonation front thus the steel/ concrete interface isn't de-passivized.

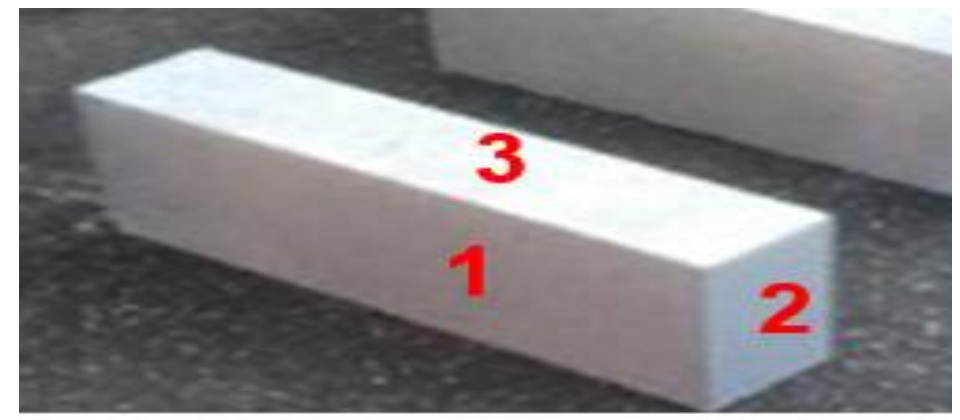

Figure 3: Block Faces Tested (410 x 210 x 95).
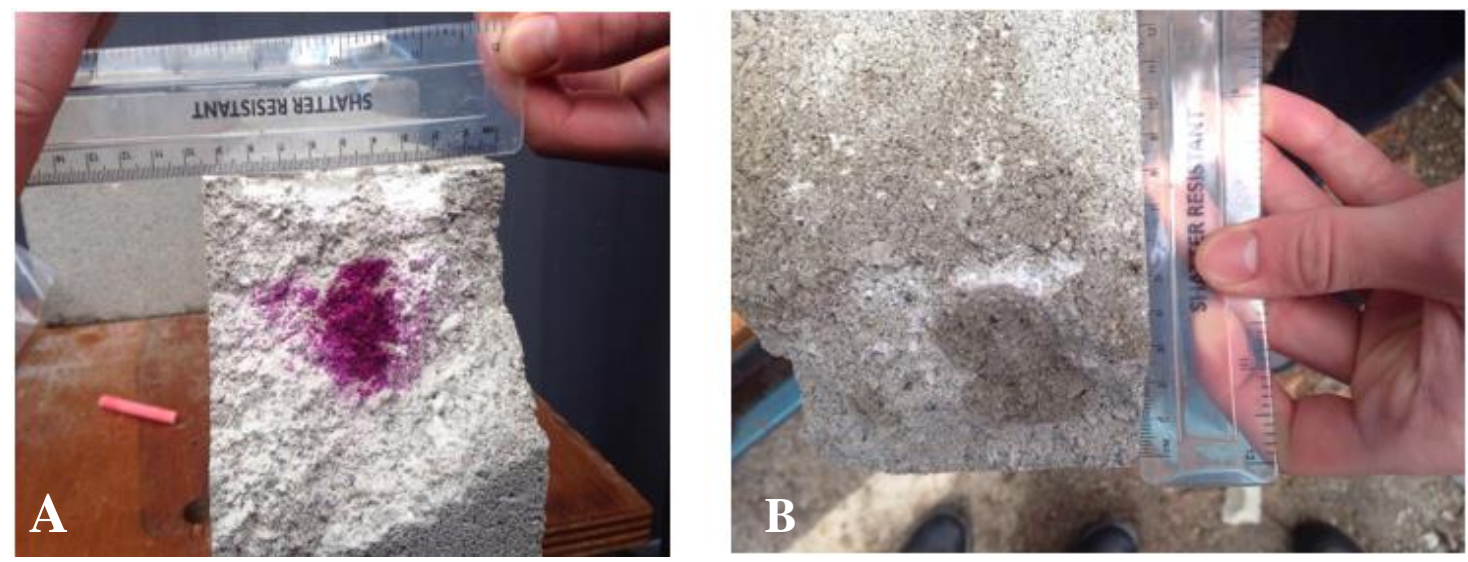

Figure 4: Depth of carbonation.

\subsection{Chloride Testing}

Chloride test used to determine the presence of chloride ions within a reinforced concrete structure due to the detrimental effect it has on the interface between the steel reinforcement. The chlorides being acid; therefore, lead to reduce alkalinity that causes de-passivation. Samples are taken at a different depth to produce a profile of chloride penetration through the structure. The samples are mixed with an indicating tablet. If the solution turned yellow, there were chlorides present, and none turned brown. Although this test cannot give any 
quantitative value of the amount of chloride present with a concrete element, however, it is an accurate and reliable test as it relies on a chemical reaction [19].

As chloride ions are transported through a solution in the concrete, so a high level of moisture content indicates a high level of chloride and vice versa. Therefore, the results of moisture content test can be used in conjunction with the results chloride test to indicate the probability of future degradation by chloride attack and assess the depth of penetration of chlorides, so this test can be used in concurrence with the Ferro scanner to determine if the depth of chloride has reached or may reach the reinforcement shortly.

\subsection{Cover Meter (Ferro Scanner) Test}

This test uses magnetic fields to determine the exact level of cover, the position and diameter of the steel reinforcement. A grid established on the column surface and then the cover meter is rolled along the lines on the grid. The readings are obtained by measuring the change in voltage caused by the presences of steel rebar within the electromagnetic field emitted by the device. The device readings are stored on the scanner and then can be transferred to a computer for analysis. Diagrams can be created to show the exact dimensions and locations of each rebar detected [20]. Ferro Scanner and Half-Cell tests combined are good at establishing partially the condition of the steel bars that is important as they provide ductility and tensile strength to the concrete. Besides, Ferro Scanner can provide an estimation to a loss in the steel reinforcement or a loss of concrete cover. Therefore, this test is important as providing an accurate cover is essential to ensure if improvements to the level have to happen to protect the reinforcing bars effectively [21].

\subsection{Half-cell corrosion potential testing (electrochemical)}

The Half Cell test is a way of predicting the corrosion that could take place using the way that steel reinforcement corrodes due to copper sulphate or CuSO4. A small amount of cover is removed, and the contact is made electrically, then the surface is wetted to create a completed circuit between the steel reinforcement and the reference electrode placed on the surface concrete as shown on Figure 5. The electrical activity of the steel reinforcement and the concrete leads them to be considered as one half of weak battery cell with the steel acting as one electrode and the concrete as the electrolyte [22].
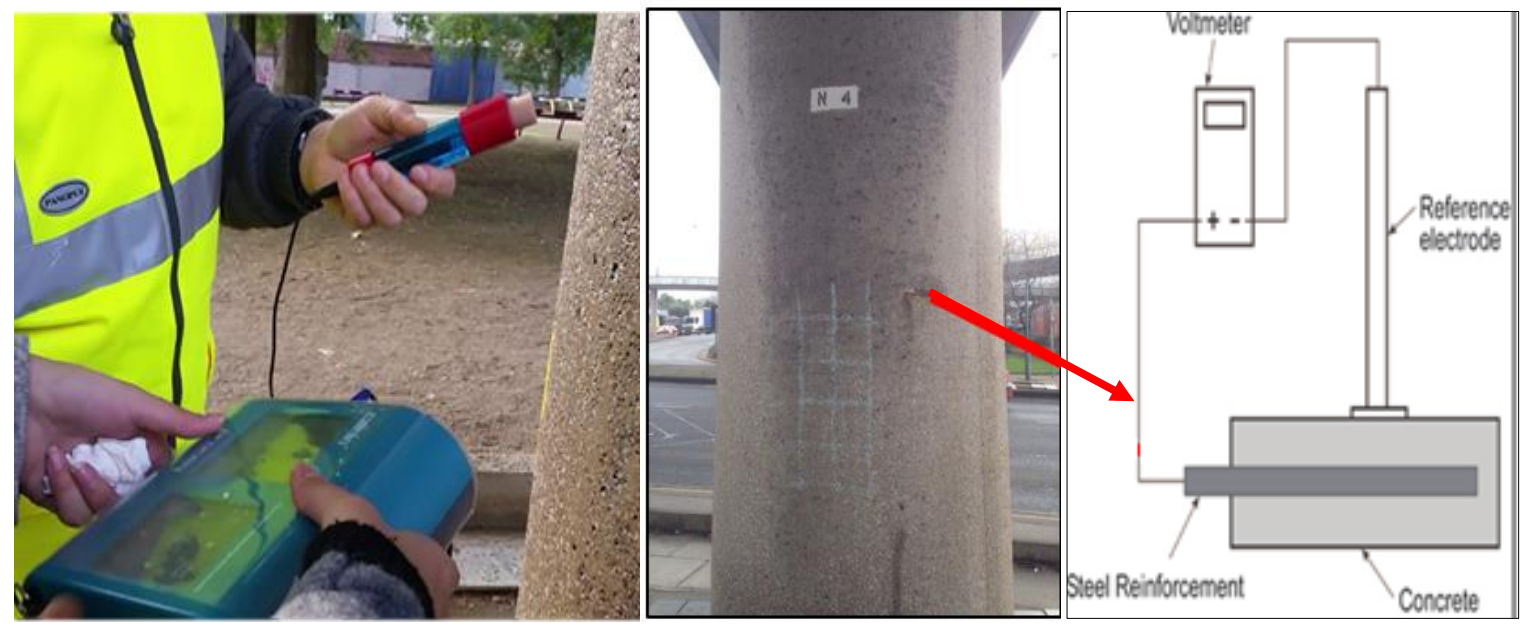

Figure 5: Conducting Half-cell corrosion potential testing.

The half-cell test is vital when investigating a concrete structure in a situation such as the case of the Churchill Way flyover. Not conducting this NDT and repairing the concrete without specifying the situation internal could be extremely counterproductive. This NDT uses a voltmeter that records results with negative values because the reference electrode is connected to the cathode. The more negative results recorded by the voltmeter, the less resistance offered by the concrete cover. This means the higher the probability corrosion has taken place within the column and according to Table 1.

Table 1: Interpretation of Half-cell test results [22].

\begin{tabular}{ll}
\hline $\begin{array}{c}\text { Half -cell potential relative to } \mathbf{C u}-\mathbf{C u} \\
\text { sulphate electrode }(\mathbf{m V})\end{array}$ & \multicolumn{1}{c}{$\begin{array}{c}\text { Chance of corrosion activity } \\
(\boldsymbol{\%})\end{array}$} \\
\hline Less than $-\mathbf{2 0 0}$ & $10 \%$ \\
Between $-\mathbf{2 0 0}$ to $-\mathbf{3 5 0}$ & $50 \%$ (uncertain) \\
\hline
\end{tabular}


Above-350 $90 \%$

\section{Results of NDTs}

\subsection{Schmidt hammer}

From Table 3 in conjunction with the results collected in Table 2, it is clear to see that the concrete has very good hard layer and it has not degraded to the point that is serious on the surface. Even removing the anomalies (highest value and lowest value) the range of rebound values measured 53.2-60.3 show there are irregularities in the surface and that points to there being an amount of corrosion of the surface. Higher compressive strength values can be interpreted in two ways: the first one may be an indication of surface carbonation. Surface carbonation causes hardening of the concrete as it permeates from the outside. The harder the concrete, at the point of contact with the Schmidt hammer, the higher the compressive strength value measured. Surface carbonation can cause an increase in compressive strength of up to 50\% [10]. However, the high strength measured at the surface may not be true of the concrete at a greater depth.

Table 2: Schmidt hammer test results for Churchill Way flyover girder.

\begin{tabular}{lllll}
\hline & $\mathbf{1}$ & $\mathbf{2}$ & $\mathbf{3}$ & $\mathbf{4}$ \\
\hline A & $\mathrm{Q}=53$ & $\mathrm{Q}=60.3$ & & \\
& $56.5 \mathrm{~N} / \mathrm{mm}^{2}$ & $90 \mathrm{~N} / \mathrm{mm}^{2}$ & & \\
B & & & & \\
C & $\mathrm{Q}=54.2$ & & & \\
& $84 \mathrm{~N} / \mathrm{mm}^{2}$ & & & \\
D & $\mathrm{Q}=59.2$ & & & \\
& $84 \mathrm{~N} / \mathrm{mm}^{2}$ & & & \\
E & $\mathrm{Q}=60.4$ & $\mathrm{Q}=59.3$ & $\mathrm{Q}=53.2$ & $64.02 \mathrm{~N} / \mathrm{mm}^{2}$ \\
& $91 \mathrm{~N} / \mathrm{mm}^{2}$ & $84.5 \mathrm{~N} / \mathrm{mm}^{2}$ & $57.5 \mathrm{~N} / \mathrm{mm}^{2}$ & 64.9 \\
\hline
\end{tabular}

Mean of Results $($ Compressive strength $)=56.5+90+84+84+91+84.5+57.5+64.02=76.44 \mathrm{~N} / \mathrm{mm}^{2}$. It is crucial to determine the initial compressive strength of the concrete being investigated to be able to identify any increase or decrease in compressive strength.

Table 3: Interpretation of the rebound value (Spectro Analytical Labs Limited, 2016).

\begin{tabular}{cl}
\hline Average Rebound Number & Quality of Concrete \\
\hline$>40$ & A very good hard layer \\
30 to 40 & Good layer \\
20 to 30 & Fair \\
$<20$ & Poor concrete \\
0 & Delaminated \\
\hline
\end{tabular}

The second one is the structure age as it has been built in the 1960s, aggregates are visible to the surface due to corrosion. Therefore, readings may have been taken from the aggregates and not from the cement matrix. If this were a genuine problem in the test, then this would result in the form of systematic error that puts the results from this test in jeopardy.

Furthermore, Figure 6 shows inconsistent marks on the joint between the column and the underside of the flyover. It suggests there has been a sprayed concrete repair in the past. This would affect the results the Schmitt hammer produce, as the concrete would be younger and not indicative of the concrete internally; the concrete that is doing the majority of the load-bearing for the structure. 


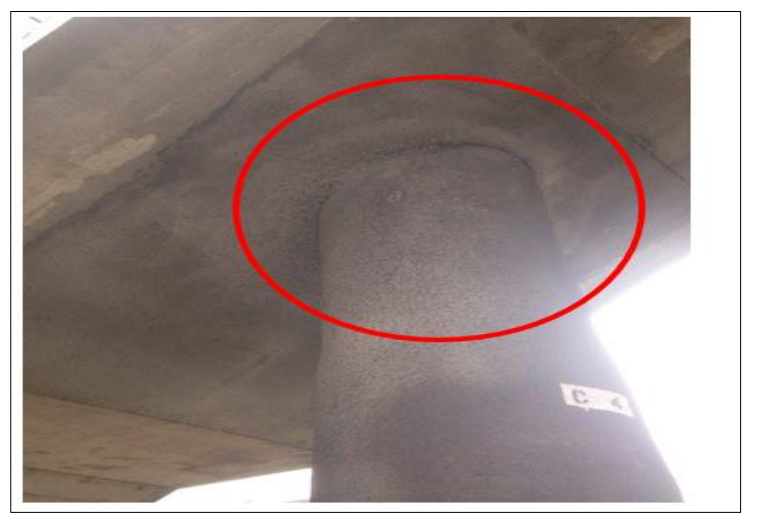

Figure 6: A portion of column C4 located under the stairs that have been repaired.

Besides, moisture content has a direct effect on concrete strength, and therefore the results of a Schmidt hammer test. A surface with a high moisture content will generate a lower rebound value [10]. Therefore, if the concrete element being tested is at risk of increased exposure to moisture, testing the moisture content will allow for the results to be adjusted accordingly. High moisture content can also infer long-term types of deterioration that affect the strength of concrete, such as corrosion by chloride attack and carbonation. Therefore, a Half- cell test can be used to investigate the likelihood of corrosion.

On the other hand, if the compressive strength readings were low, this would indicate the concrete to be more permeable, meaning greater voids prone for attacks. When the chloride content at the surface of the steel exceeds the threshold value, corrosion will occur if water and oxygen are available. Freeze-thaw attacks are possible to the concrete structure given the environment in Liverpool, England, with a wide range of weather conditions. For confirming corrosion in the rebar, data from a Ferro scan could be used to determine the loss in a section of the rebar where the Schmidt hammer test was taken.

\subsection{Moisture content}

Firstly, the Portimeter or Moisture tester has been used, which only gives a reading to compare with similar materials. This can be used to show where the greatest presence of moisture is on a large concrete structure. Once determined, the speedy moisture instruments can be used to collect more accurate results that can be quoted in a report.

The results in Table 5 show that the moisture content is slightly high for the wet block compared to the other sets of results with a dry block shown in Table 4. However, the wet block moisture content is not consistent with the Wet block. If the anomaly is removed (7.5\%), the results confirm that moisture content decreases when you go deeper into the concrete structure.

However, the $7.5 \%$ moisture content for the wet block shows a higher level of moisture present to a greater depth. As chlorides are transported in solution to the steel reinforcement where they can cause detrimental corrosion, it is important to detect the location of the steel reinforcement in areas with higher moisture content. A Ferro scanner can be used to discover the depth of cover, along with the moisture content results can be determined if the moisture content, at $40 \mathrm{~mm}$, is will reach the depth of the rebar. Due to the exposure conditions and according to Euro code 2, the Churchill way flyover should have a concrete exposure class of XD3; which means a cover of 50mm. This means a large passive concrete layer. However, on visual inspection, it is clear that have either not been used in the design or simply been corroded away, as steel reinforcement is showing [7].

Table 4: Speedy moisture test results for sample Block A (Dry).

\begin{tabular}{ll}
\hline Depth of Sample Taken $(\mathbf{m m})$ & Percentage Wet Weight $(\boldsymbol{\%})$ \\
\hline $\mathbf{5}$ & 0.75 \\
$\mathbf{2 0}$ & 0.55 \\
$\mathbf{3 0}$ & 0.50 \\
\hline
\end{tabular}


Table 5: Speedy moisture test results for sample Block B (Wet).

\begin{tabular}{ll}
\hline Depth of Sample Taken $(\mathbf{m m})$ & Percentage Wet Weight $(\%)$ \\
\hline $\mathbf{1 0}$ & 6.7 \\
$\mathbf{2 0}$ & 5.7 \\
$\mathbf{3 0}$ & 7.5 \\
$\mathbf{4 0}$ & 5.3 \\
\hline
\end{tabular}

\subsection{Depth of carbonation}

When compared with the other two sides, it seems to support the theory that it was sitting in a pile with a side ( $95 \mathrm{~mm}$ ) face down. Side $2+3$ have considerably more de-passivation, carbonation present to a depth of about $40 \mathrm{~mm}$. The carbonation rate is fast in a breezeblock as it has a lower density than most concrete, higher porosity and is made from Mersey silt, unlike some other concrete. If this had been in a building the likelihood that the carbonation front may have reached the reinforcement leading to the steel being vulnerable to chemical attack. The time may cause the structure to become structurally defective without the external warning signs as with other forms of degradation.

\subsection{Chloride test}

Table 6 shows the results from a concrete cube, which had been submerged in a salt solution for a year. The chloride penetration profile obtained shows the chlorides have reached the depth of the centre of the cube at $75 \mathrm{~mm}$. This indicated that the whole cube had been penetrated with chlorides. Although the cube had been in an enclosed environment in the lab, it had traces of chloride present. The chloride was consistent throughout the cube, with high salinity levels that been shown by the high intensity of the yellow colour left after the solution had settled.

Table 6: A Chloride test results for the concrete cube.

\begin{tabular}{lll}
\hline $\begin{array}{c}\text { Depth Drilled into a } \\
\text { cube }(\mathbf{m m})\end{array}$ & $\begin{array}{c}\text { Solution Colour } \\
\text { after Chloride } \\
\text { Tablet }\end{array}$ & Chloride Present \\
\hline $\mathbf{5}$ & Yellow & Yes \\
$\mathbf{1 0}$ & Yellow & Yes \\
$\mathbf{2 0}$ & Yellow & Yes \\
$\mathbf{3 0}$ & Yellow & Yes \\
$\mathbf{4 0}$ & Yellow & Yes \\
$\mathbf{7 5}$ & Yellow & Yes \\
\hline
\end{tabular}

Table 7: A Chloride test results for sample Block.

\begin{tabular}{lll}
\hline $\begin{array}{c}\text { Depth Drilled into } \\
\text { Block }(\mathbf{m m})\end{array}$ & $\begin{array}{c}\text { Solution Colour } \\
\text { after Chloride } \\
\text { Tablet }\end{array}$ & Chloride Present \\
\hline $\mathbf{5}$ & Brown & No \\
$\mathbf{1 0}$ & Brown & No \\
\hline
\end{tabular}

The cube may not have been exposed to chloride from the atmosphere, but the concrete mix with the use of local materials. The sand used for the concrete mix was Mersey Grit; this is taken from the River Mersey. Chlorides that naturally exist in the sea in the form of sodium chloride that in the concrete mixture leads to sodium hydroxide. These chlorides through tidal movement concentrated in Mersey, and grit settled at the river bed. However, it is impossible to separate all salt particles when dredging sand from the River Mersey. Location is key when investigating a concrete structure. Investigating the local materials used for construction projects may identify sources of degradation of concrete. Some parts of the Churchill Flyover may not be close to the road and in contact with road salts but may still have chloride attacking it due to the materials used in the mix design of the concrete. 
This test does not represent a correct analogue that the column N4 shown in Figure 7. From Churchill way flyover because the concrete flyover structure will not be as permeable as the concrete cube due to the mix design established for the structures primary use. Besides, the structure will be more exposed to road salt activities. Therefore, if dust were to be taken from the column N4, it would be easy to determine if chlorides were present. Due to the age of the structure, about 47 years old, chloride maybe has been included in the mix design. 'Calcium chloride was used as an accelerating admixture in concrete up until the mid-1970s' [23].

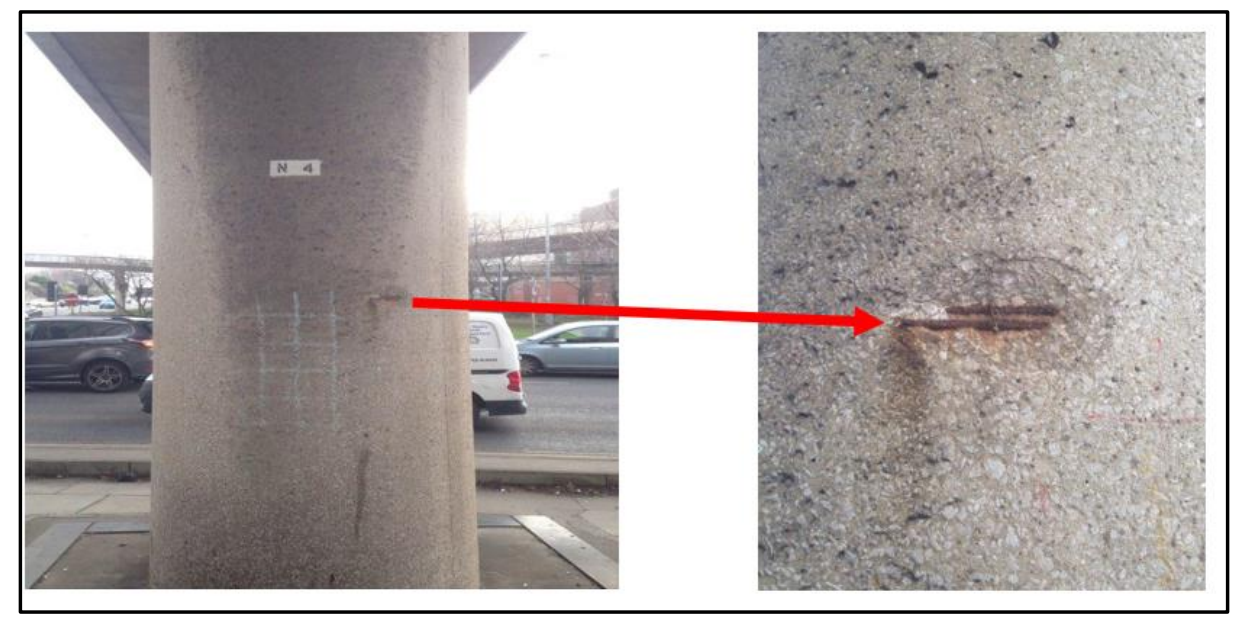

Figure 7: Exposed Reinforcement layer for column N4.

Once chlorides are present within the concrete, it will start to decrease the natural $\mathrm{pH}$ of the concrete. This will induce corrosion around the concrete. Once corrosion begins to form, it continues to expand, causing surface cracks that can be extended to pushing the concrete out, as shown in Figure 8. This diagram represents iron within a water solution along the $\mathrm{X}$-axis, corrosion starts around $\mathrm{pH} 9$, as shown in Figure 9. This supports the previous claim. The results in Table 7 above show that the breezeblock at $5 \mathrm{~mm}$ and $10 \mathrm{~mm}$ depth showed no chlorides present. This would suggest at the block side that had been exposed to weather, and other contaminants were on the opposite side to the side that the drilling process took place. Therefore, a concrete member under the same condition could be expected to have no corrosion due to chloride attack.

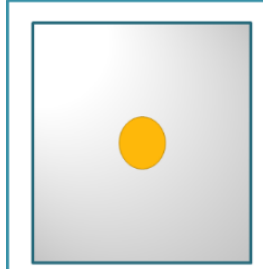

Before Corrosion

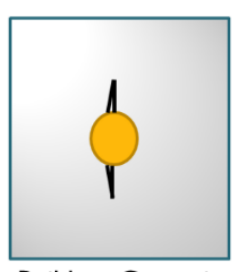

Build-up Corrosion

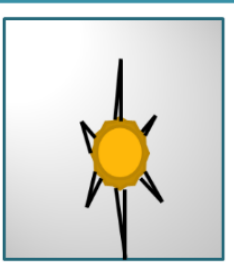

Further Corrosion: Surface Cracks, Stains

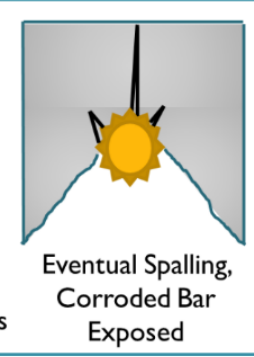

Figure 8: The expansion of corroding steel [24].

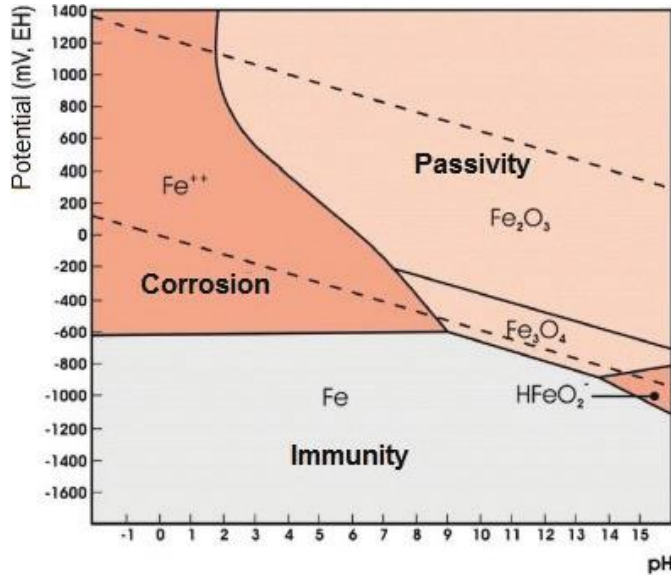

$(+100 \mathrm{mV})$

Typical ranges of in concrete $(-400 \mathrm{mV})$

Figure 9: Pourbaix diagram [25]. 


\subsection{Cover Meter}

The graph in Figure 10 shows that any diameter recorded with a cover over $40 \mathrm{~mm}$, the results become less reliable. Even with the error that greater cover gives, however, you would likely be able to show the difference between main bars and the secondary reinforcements that both run vertically in a column, and the link bars that run horizontally. This supported by the fact that the vertical (main bars) are set behind link bars, as they have a greater cover.

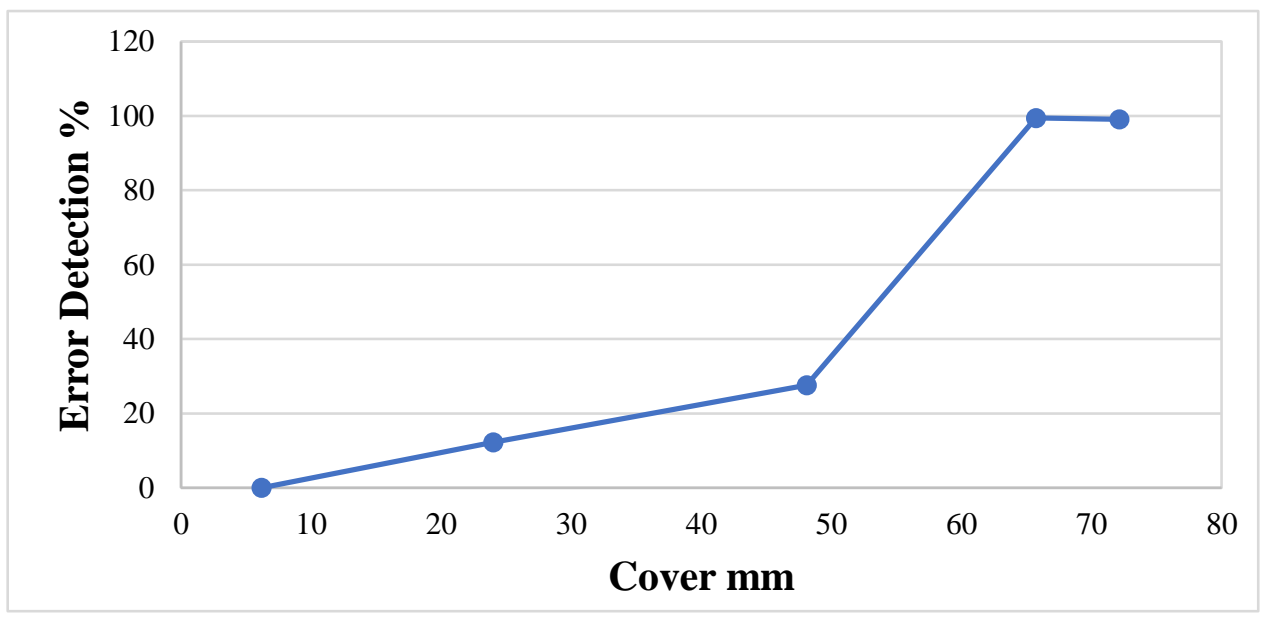

Figure 10: Error in detecting rebar diameter with increasing cover depths [21].

Table 8 and Figure 11 showed the results of a Ferro scan that been conducted on a concrete girder; these results only show the depth of cover and rebar diameter. Also, Figure 11 shows that there are some irregularities; this is reflected in Table 8 with one cover values being $98 \mathrm{~mm}$. These irregularities could be linked to the human error in this experiment, where the scanner may not roll across the correct section. As mentioned before the suggested class for this girder is XD3, this would mean a cover of 50mm according to EC2.

For the first horizontal bars shown in Table 8, the bar diameter ranging from 8-12 mm, and only one result shows that the bar diameter is $14 \mathrm{~mm}$. The $14 \mathrm{~mm}$ bar diameter can be interpreted in two ways: the first one is the original bar diameter is H12, but this bar rusted and became larger. However, the second one is the original bar diameter is H16, and this bar has been corroded away to become smaller.

The results of cover for the vertical bars are ranging from 39-47 which is within class XD3 guidelines, and this is good as the most critical steel bars still have a minimum cover of $39 \mathrm{~mm}$ which is still considered a good healthy protection layer. However, the bar diameter recorded are very different and ranging from 16-36mm. This difference in results can be interpreted in three ways: the first one demonstrated in Table 9, there are some results recorded at the $\mathrm{Y}$-axis for horizontal bars around 340 and 420 . These results might be the results of lapping bars where two ends of steel bars meet. When two metal bars are close to each other, it might cause an interaction to the magnetic field of these bars that could be disrupting the information the scanner receives. The second one can be attributed to pit corrosion that can reduce the diameter of the bar that the Ferro Scanner is possibly reading. The last one is, as almost all the vertical bars have a cover of $40 \mathrm{~mm}$ or more, so the results recorded by the Ferro Scanner became less reliable as explained before depending upon Figure 11. 


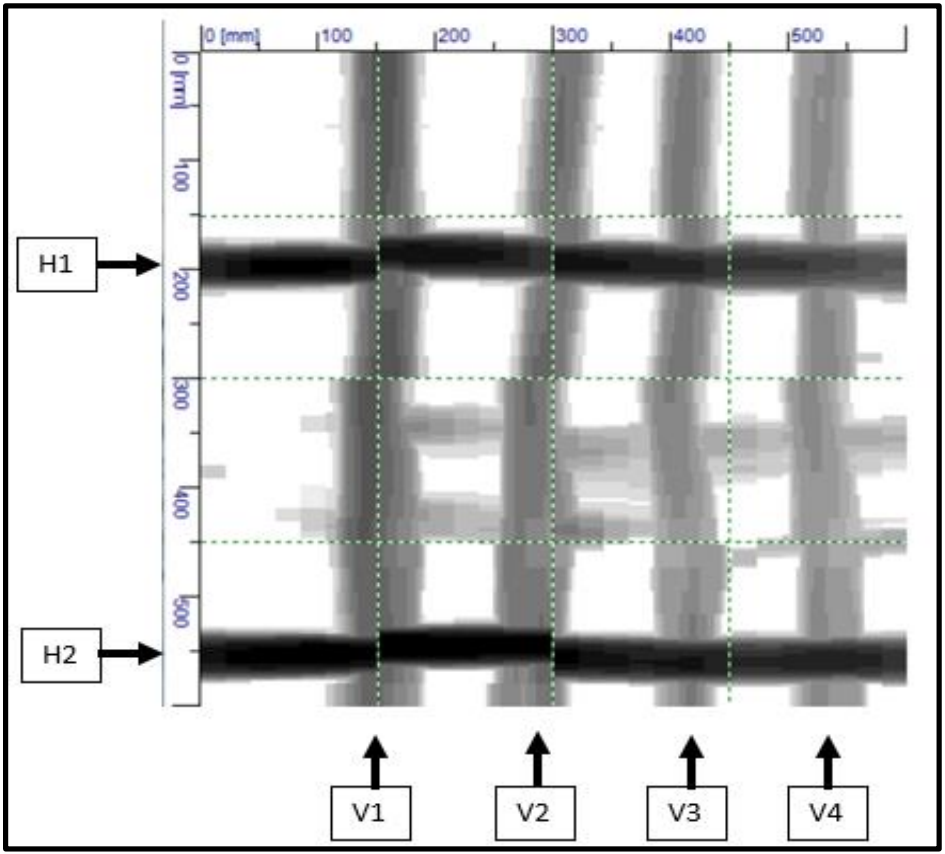

Figure 11: An image from the Ferro scanner created using the data from Table 8.

Table 8: The data collected by the Ferro Scanner.

\begin{tabular}{|c|c|c|c|c|}
\hline $\mathbf{X}(\mathbf{m m})$ & $\mathbf{Y}(\mathbf{m m})$ & $\begin{array}{l}\text { Coverage } \\
\mathrm{mm}\end{array}$ & Diameter & Orientation \\
\hline 160 & 58.3 & 98 & $6 \mathrm{~mm}$ & $\mathrm{H}$ \\
\hline 160 & 185 & 20 & $10 \mathrm{~mm}$ & $\mathrm{H}$ \\
\hline 395.7 & 196 & 25 & $14 \mathrm{~mm}$ & $\mathrm{H}$ \\
\hline 95.7 & 196 & 18 & $8 \mathrm{~mm}$ & $\mathrm{H}$ \\
\hline 524.3 & 196.2 & 28 & $12 \mathrm{~mm}$ & $\mathrm{H}$ \\
\hline 417.1 & 197.2 & 24 & $12 \mathrm{~mm}$ & $\mathrm{H}$ \\
\hline 160 & 340.3 & 36 & $6 \mathrm{~mm}$ & $\mathrm{H}$ \\
\hline 417.1 & 360.8 & 53 & $6 \mathrm{~mm}$ & $\mathrm{H}$ \\
\hline 160 & 421.9 & 42 & $6 \mathrm{~mm}$ & $\mathrm{H}$ \\
\hline 95.7 & 429.1 & 68 & $6 \mathrm{~mm}$ & $\mathrm{H}$ \\
\hline 160 & 541.7 & 17 & $12 \mathrm{~mm}$ & $\mathrm{H}$ \\
\hline 95.7 & 549.6 & 18 & $10 \mathrm{~mm}$ & $\mathrm{H}$ \\
\hline 524.3 & 554 & 23 & $10 \mathrm{~mm}$ & $\mathrm{H}$ \\
\hline 395.7 & 554.7 & 23 & $12 \mathrm{~mm}$ & $\mathrm{H}$ \\
\hline 417.1 & 555.2 & 21 & $10 \mathrm{~mm}$ & $\mathrm{H}$ \\
\hline 155.7 & 74.3 & 40 & $36 \mathrm{~mm}$ & V \\
\hline 155.8 & 52.9 & 39 & $30 \mathrm{~mm}$ & $\mathrm{~V}$ \\
\hline 156 & 95.7 & 40 & $36 \mathrm{~mm}$ & V \\
\hline 159.7 & 202.9 & 43 & $36 \mathrm{~mm}$ & V \\
\hline 303.6 & 202.9 & 45 & $30 \mathrm{~mm}$ & V \\
\hline 304.2 & 95.7 & 44 & $30 \mathrm{~mm}$ & V \\
\hline 305.5 & 74.3 & 44 & $30 \mathrm{~mm}$ & V \\
\hline
\end{tabular}




\begin{tabular}{ccccc}
\hline $\mathbf{3 0 7 . 4}$ & 52.9 & 44 & $28 \mathrm{~mm}$ & $\mathrm{~V}$ \\
$\mathbf{4 0 8 . 2}$ & 95.7 & 44 & $25 \mathrm{~mm}$ & $\mathrm{~V}$ \\
$\mathbf{4 0 8 . 7}$ & 74.3 & 44 & $25 \mathrm{~mm}$ & $\mathrm{~V}$ \\
$\mathbf{4 0 9 . 6}$ & 52.9 & 45 & $25 \mathrm{~mm}$ & $\mathrm{~V}$ \\
$\mathbf{4 1 2 . 5}$ & 202.9 & 45 & $28 \mathrm{~mm}$ & $\mathrm{~V}$ \\
$\mathbf{5 2 0 . 7}$ & 95.7 & 47 & $16 \mathrm{~mm}$ & $\mathrm{~V}$ \\
$\mathbf{5 2 0 . 7}$ & 74.3 & 47 & $16 \mathrm{~mm}$ & $\mathrm{~V}$ \\
$\mathbf{5 2 1 . 2}$ & 52.9 & 47 & $16 \mathrm{~mm}$ & $\mathrm{~V}$ \\
$\mathbf{5 2 4 . 7}$ & 202.9 & 49 & $20 \mathrm{~mm}$ & $\mathrm{~V}$ \\
\hline
\end{tabular}

\subsection{Half-cell corrosion potential Results}

The results in Table 9 used in conjunction, the main findings are: Readings A1, B1, D1 and B2 have indicated an increased probability of corrosion as their results show values of higher than -200 millivolts. Also, as all the other results show values of less than -200 millivolts, so this means that they have a minimal probability of corrosion and the steel reinforcement in those areas is still in an alkaline environment. There are some other factors to consider when interpreting results such as oxygen levels throughout the structure, temperature, carbonation and concrete electrical resistance linked to surface wetting sufficient which if they take place they might change the reading and if they aren't acknowledged the results are less valuable.

The first factor is the oxygen level (oxidization layers) formed on the surface of the exposed steel reinforcement affect the readings that the half-cell test produces. This result in higher resistivity that also means a higher millivolt reading suggesting there is less corrosion than there is. However, this is not always representative of the corrosion that exists internally because this concrete as the Schmidt hammer showed has a high density; therefore, the porosity is lower. Therefore, a lower reading may be produced but does not necessarily mean a lower likelihood of corrosion. As the exposed steel reinforcement on column $\mathrm{N} 4$ has been exposed for some time, meaning that there will likely be a strong oxidization layer formed on top. This could mean that the results gained have underestimated the severity of the situation.

The second factor is a temperature that can considerably affect the readings of the half-cell test. Lower readings may produce if test conducted in lower temperature. Although constant temperature can cause inaccurate results, however, it could provide a valid representation of the areas of increased corrosion potential.

The third factor that may affect the readings of the half-cell test is carbonation. As mentioned before, theory and results for carbonation suggest that column $\mathrm{N} 4$ has subjected some carbon ingression within the concrete. If carbonation occurs, it will seriously be lowering the alkalinity of the concrete/ steel interface, and it will cause the reading from the half-cell test to be significantly higher suggesting less corrosion than the concrete has. Therefore, a carbonation test is required before to ensure the sort of corrosion has started at the reinforcement [13].

The last factor is that the concrete may have a resistance electrically, which can make the experiment inaccurate when determining the level of copper sulphate corrosion that was being tested. The main way to reduce it is by wetting the surface that improving the pathway for the circuit. Although, if the concrete has a high permeability, the water will not penetrate to a layer where the resistance would be completely eradicated. The dried water on the surface or absorbed into the concrete was due to the variance in the results [20].

Table 9: Results of the half-cell test.

\begin{tabular}{ccccc}
\hline & $\mathbf{A}$ & $\mathbf{B}$ & $\mathbf{C}$ & $\mathbf{D}$ \\
\hline $\mathbf{1}$ & $-229 \mathrm{mV}$ & $-218 \mathrm{mV}$ & $-162 \mathrm{mV}$ & $-206 \mathrm{mV}$ \\
$\mathbf{2}$ & $-170 \mathrm{mV}$ & $-224 \mathrm{mV}$ & $-130 \mathrm{mV}$ & $-190 \mathrm{mV}$ \\
$\mathbf{3}$ & $-177 \mathrm{mV}$ & $-93 \mathrm{mV}$ & $-134 \mathrm{mV}$ & $-146 \mathrm{mV}$ \\
$\mathbf{4}$ & $-48 \mathrm{mV}$ & $-180 \mathrm{mV}$ & $-44 \mathrm{mV}$ & $-177 \mathrm{mV}$ \\
\hline
\end{tabular}

\section{General Discussion and Summary}

The tests that have been conducted on the Churchill Way flyover were destructive and non-destructive, which both of them are useful when they used together to present an idea of the condition of the concrete structure. This is because if these tests being used individually, they are incapable of providing a full idea of how much 
of the strength, cover, and passivation remain. This can be attributed to that each test being effected by multiple aspects of the concrete, so drawing one particular conclusion from only a single test would have an inaccurate outcome with many factors not taken into account.

For example, the Schmidt hammer test that has been carried out to find the residual compressive strength of the concrete, which is very important. For identifying the structure capacity to resist the axial loads that it's required to; but also, because compressive strength is an indicator of density. The stronger compressively, the denser due to the lower $\mathrm{W} / \mathrm{C}$ ratio that reducing the number of voids in the concrete, this in turns will reduce the speed of carbonation as $\mathrm{CO} 2$ takes longer to propagate through the concrete.

Because the Schmidt hammer test is only recorded the compressive strength on the outside layer of the structure that can be affected by previous repairs or aggregate, so this test cannot provide any indications of the internal conditions of the concrete structure. The use of the Schmidt hammer test in conjunction with the Ferro scanner tests allow discovering the level remaining cover. The level of cover the test produced varied but many results were over $40 \mathrm{~mm}$ that would be sufficient to resist carbonation, the test did produce values that were lower, but this could be attributed to the instrument miscalculating the feedback from the reinforcing bars and therefore inaccuracies with the provided results. Although the Ferro scanner test is a good indicator for whether the steel is protected, however, without the half-cell test to determine if contaminants or chloride attack has started it is not sufficient to determine the state of the concrete internally.

If the results of the half-cell test show that there may be other forms of degradation in the concrete protective layer, then the destructive carbonation test would be conducted. This would allow the determination of the carbonation profile within the concrete that would find if the concrete was protecting the steel effectively. Then the state of passivation would be investigated by drilling in and conducting a chloride test that would be crucial because the presence of chlorides in a de-passivized concrete can rapidly accelerate the corrosion of steel and as the steel is vital for offering the axial loading support and tensile strength that the flyover requires with the traffic it accommodates.

As mentioned before that the Churchill Way flyover has been repaired in some areas and the NDTs needed to assess the quality of repairs in those areas which they are located by the main road where there is a high-level exposure to more chloride attack from de-icing salts. Up to the mid-1970s, calcium chloride was used as an additive to the concrete mix to be a catalyst to make the curing process faster. However, it chemically reacts and turns into calcium hydroxide that corrodes the steel rather than protects it. As Churchill Way flyover was constructed in 1969, so calcium chloride might be used within the concrete mix design of this structure. However, the structure probably would be showing more structural insignificances if it had been built using this particular method.

\section{Visual Inspection}

Although NDTs are comprehensive and they should be performed when carrying out any concrete structural inspection, however, a walk over to visually investigate the conditions of a structure, the loading on it and any addition or alterations is sometimes the most revealing aspect. A visual inspection of Churchill Way flyover was conducted on 14/02/2017. Visually it has been seen that the column supporting the stairs had been subject to repair works. This can be interpreted that the structure was undergone concrete attacks. Also, along the public walkway repair works have been conducted extensively, this could be attributed to the failing of water membrane, as shown in Figure 12. Besides, the public walkway, there are many places of exposed reinforcement layer; this can be attributed to de-passivation of concrete when its $\mathrm{pH}$ became around 9.
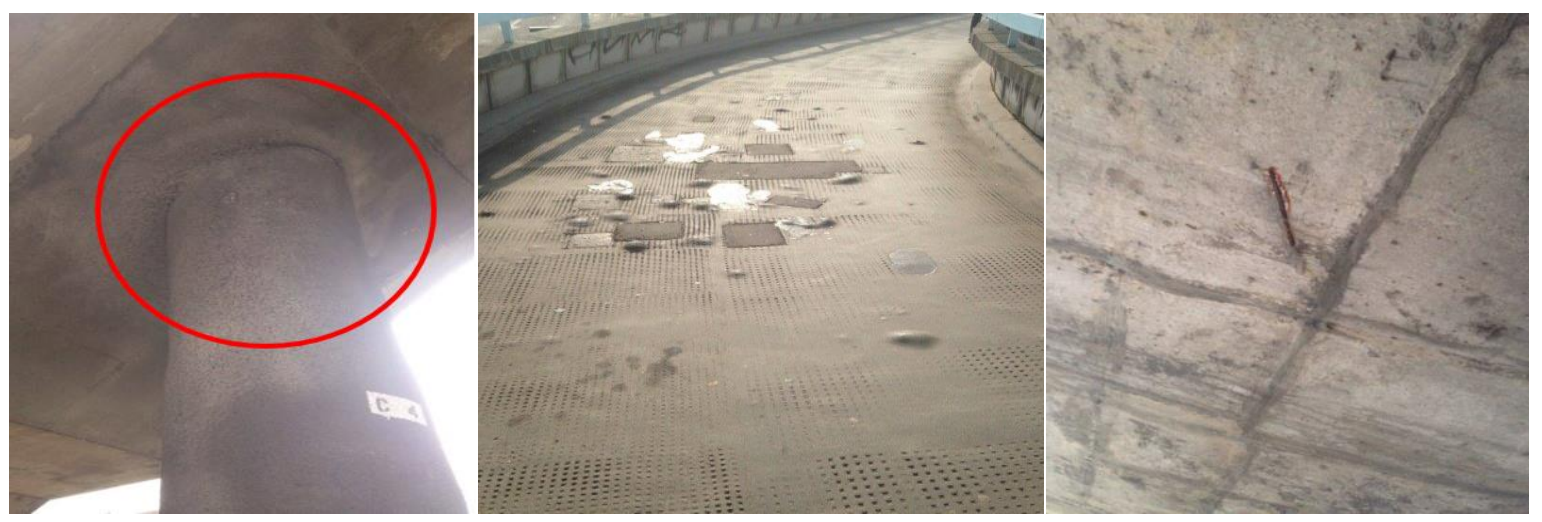

Figure 12: Defaults and cracks in Churchill Way flyover. 


\section{Recommendations for Repairs}

The carbonation test has been shown that there was some carbonation attack, so a destructive carbonation test should be conducted to assess the problem. If the problem is much further onset than expected a process of recovering the alkalinity of the concrete should be started. This process that induces re-alkalization by applying an alkali solution to the surface and covering the concrete in an electrode net to encourage the movement of alkali solution to the reinforcing bars inside the concrete [26], [27].

The NDTs that have been conducted have shown signs of corrosion and have indicated there may be issued with chlorides both externally from de-icing salts and internally from potential Mersey grit and calcium chloride. However, on every quantifiable level, the corrosion lies in controllable levels. Therefore, a recommendation would be to repair the structural visually now and save incurring further costs in the future because the aesthetics of the building are becoming a serviceability problem.

Finally, all the areas highlighted as high-risk need to be monitored and tested regularly, for example checking that the bar diameter size is still adequate or there will be a need for a more intrusive method of repair.

\section{Conclusion}

In the UK degradation to reinforced concrete structures mainly tends to be from sources of carbonation and chloride, resulting in corrosion. All of the tests conducted on the structure showed it to be within allowable parameters.

i.

The Schmidt hammer test as a fast test can identify a serious problem with the structure due to the carbonation or chloride attack that has taken place and then repaired. The results show that the repairs that have taken place are not degrading as fast as the original concrete.

ii. The speedy moisture test is accurate for use on structures with columns facing the flow of traffic being more in contact with carbon dioxide emissions and the winter splashback from road salts causing chloride attacks.

iii. Potential causes for decreasing the cover of the horizontal bars can be attributed to both chloride attack and carbonation that may cause de-passivation of the cover around the steel rebar due to its location beside the large main road, where $\mathrm{CO} 2$ and road salts are very much available.

iv. Half-cell test considered as a non-destructive test, but the conducting of the test need to expose rebar, often it is necessary to damage the concrete surface to expose the rebar. Thus, removing the cover from the reinforcement leaves it susceptible to corrosion, which in turns will affect the structural integrity of the element.

When looking at bridge construction technology from a different point of view, the introduction of concrete technology in the construction of bridges greatly contributes to reducing concrete deterioration and in preventing or inhibiting aggressive ions such as chlorides from entering into the concrete. Where previous work [28] has shown that the use of supplementary cementitious materials (SCM) can increase the service life of bridges in addition to reducing carbon dioxide emissions by reducing the cement content. Accordingly, the authors recommend investigating the effect of SCM such as fly ash, ground granulated blast furnace slag, metakaolin, silica fume, rice husks ash, waste paper, [29], [30], [39], [40], [31]-[38] and other SCMs [41]-[45] commonly used as substitutes for the cement to investigate their impact on the service life of bridges and thus including them in future structures. In addition to that, the use of industrial waste or by-products [33], [46], [55]-[59], [47]-[54] is considered a worthy topic in improving concrete technology in general from an environmental perspective and towards sustainability.

Conflict of interest: The authors declare no conflict of interest to any party.

\section{References}

[1] W. K. Tuama, M. M. Kadhum, N. A. Alwash, Z. S. Al-Khafaji, and M. S. Abdulraheem, "RPC Effect of Crude Oil Products on the Mechanical Characteristics of Reactive-Powder and Normal-Strength Concrete," Periodica Polytechnica Civil Engineering, 2017.

[2] A. A. F. Shubbar, W. Atherton, H. M. Jafer, A. F. Dulaimi, and D. Al-Faluji, "The Development of a New Cementitious Material Produced from Cement and GGBS," in The 3rd BUiD Doctoral Research Conference-Faculty of engineering and IT, 2017, pp. 51-63.

[3] A. A. Al-Musawi, A. A. H. Alwanas, S. Q. Salih, Z. H. Ali, M. T. Tran, and Z. M. Yaseen, "Shear strength of SFRCB without stirrups simulation: implementation of hybrid artificial intelligence model," Engineering with Computers, vol. 36, no. 1, pp. 1-11, Jan. 2020.

[4] A. K. M. A. Islam, A. S. Jaroo, and F. Li, "Bridge load rating using dynamic response," Journal of Performance of Constructed Facilities, vol. 29, no. 4, p. 4014120, 2015.

[5] M. H. Bin Afzal, S. Kabir, and O. Sidek, “An in-depth review: Structural health monitoring using fiber 
optic sensor," IETE Technical Review, vol. 29, no. 2, pp. 105-113, 2012.

[6] M. M. Obeid et al., "Electronic and magnetic properties of single-layer boron phosphide associated with materials processing defects," Computational Materials Science, 2019.

[7] A. N. Abbas, H. K. Al-Naely, H. H. Abdulzahra, and Z. S. Al-Khafaji, "Structural behavior of reinforced concrete beams having construction joint at different elevation."

[8] S. M. Awadh, H. Al-Mimar, and Z. M. Yaseen, "Groundwater availability and water demand sustainability over the upper mega aquifers of Arabian Peninsula and west region of Iraq," Environment, Development and Sustainability. 2020.

[9] W. H. Hartt, R. G. Powers, V. Leroux, and D. K. Lysogorski, "Critical literature review of highperformance corrosion reinforcements in concrete bridge applications," United States. Federal Highway Administration. Office of Infrastructure ..., 2004.

[10] T. C. S. No, "Guidebook on non-destructive testing of concrete structures," Training Course Series, 2002.

[11] N. Rankin, Churchill's Wizards: The British Genius for Deception 1914-1945. Faber \& Faber, 2008.

[12] B. Pritchard, Bridge design for economy and durability: Concepts for new, strengthened and replacement bridges. Thomas Telford, 1992.

[13] P. Domone and J. Illston, Construction materials: their nature and behaviour. CRC Press, 2010.

[14] Z. S. Al Khafaji and F. Ruddock, "Study the retardant effect of using different sugar's types on setting time and temperature of cement paste," International Journal of Civil Engineering and Technology, vol. 9, no. 1, pp. 519-530, 2018.

[15] L. Diop et al., "The influence of climatic inputs on stream-flow pattern forecasting: case study of Upper Senegal River,” Environmental Earth Sciences, vol. 77, no. 5, p. 182, 2018.

[16] "Portland Cement, Third edition." Thomas Telford Ltd, 2011.

[17] A. D. Neuwald, "Water-to-cement ratio and aggregate moisture corrections," Precast Magazine, 2010.

[18] M. Peneder, S. Kaniovski, and B. Dachs, "What follows tertiarisation? Structural change and the role of knowledge-based services," Service Industries Journal, 2003.

[19] P. Skoglund, "Chloride transport and reinforcement corrosion in the vicinity of the transition zone between substrate and repair concrete." KTH, 2006.

[20] B. Elsener, C. Andrade, J. Gulikers, R. Polder, and M. Raupach, "Half-cell potential measurementsPotential mapping on reinforced concrete structures," Materials and Structures, vol. 36, no. 7, pp. 461471, 2003.

[21] K. Sivasubramanian, K. P. Jaya, and M. Neelemegam, "Covermeter for identifying cover depth and rebar diameter in high strength concrete," International Journal of Civil \& Structural Engineering, vol. 3, no. 3, pp. 557-563, 2013.

[22] R. Dineshkumar, C. Harikaran, and P. Veerapandi, "Corrosion Assessment in Reinforced Concrete Elements using Half-Cell Potentiometer-A Review," measurement, vol. 9, p. 12, 2020.

[23] A. Dulaimi, H. Al Nageim, F. Ruddock, and L. Seton, "Laboratory Studies to Examine the Properties of a Novel Cold-Asphalt Concrete Binder Course Mixture Containing Binary Blended Cementitious Filler," Journal of Materials in Civil Engineering, vol. 29, no. 9, p. 4017139, 2017.

[24] A. G. Association, "Hot-dip galvanizing for corrosion protection a specifier's guide," Centennial, CO: American Galvanizers Association, 2012.

[25] S. H. Drissi, P. Refait, M. Abdelmoula, and J.-M. R. Génin, "The preparation and thermodynamic properties of $\mathrm{Fe}$ (II) $\square \mathrm{Fe}$ (III) hydroxide-carbonate (green rust 1); Pourbaix diagram of iron in carbonate-containing aqueous media," Corrosion science, vol. 37, no. 12, pp. 2025-2041, 1995.

[26] S. Rutledge, M. Kowalsky, R. Seracino, and N. Nau, "Repair of damaged circular reinforced concrete columns by plastic hinge relocation," Proceedings of the 15 WCEE, Lisbo, 2012.

[27] M. Z. Jumaat, M. H. Kabir, and M. Obaydullah, "A review of the repair of reinforced concrete beams," Journal of Applied Science Research, vol. 2, no. 6, pp. 317-326, 2006.

[28] N. Al-Ayish, O. During, K. Malaga, N. Silva, and K. Gudmundsson, "The influence of supplementary cementitious materials on climate impact of concrete bridges exposed to chlorides," Construction and Building Materials, vol. 188, pp. 391-398, 2018.

[29] Z. A. Hasan, M. S. Nasr, and M. K. Abed, "Combined Effect of Silica Fume, and Glass and Ceramic Waste on Properties of High Strength Mortar Reinforced With Hybrid Fibers," International Review of Civil Engineering, vol. 10, no. 5, pp. 267-273, 2019.

[30] H. Z. Kubba, M. S. Nasr, N. M. Al-Abdaly, M. K. Dhahir, and W. N. Najim, "Influence of Incinerated and Non-Incinerated waste paper on Properties of Cement Mortar," in IOP Conference Series: Materials Science and Engineering, 2020, vol. 671, no. 1.

[31] A. A. Shubbar, M. Sadique, P. Kot, and W. Atherton, "Future of clay-based construction materials-A review," Construction and Building Materials, vol. 210, pp. 172-187, 2019. 
[32] A. A. Shubbar, M. Sadique, H. K. Shanbara, and K. Hashim, "The Development of a New Low Carbon Binder for Construction as an Alternative to Cement," in Advances in Sustainable Construction Materials and Geotechnical Engineering, Springer, 2020, pp. 205-213.

[33] A.-H. Mohammed et al., "Electrochemical removal of nitrate from wastewater," in IOP Conference Series: Materials Science and Engineering, 2020, vol. 888, no. 1, p. 12037.

[34] A. A. Shubbar et al., "Properties of cement mortar incorporated high volume fraction of GGBFS and CKD from 1 day to 550 days," Journal of Building Engineering, vol. 30, 2020.

[35] H. S. Majdi et al., "Experimental data on compressive strength and ultrasonic pulse velocity properties of sustainable mortar made with high content of GGBFS and CKD combinations," Data in Brief, vol. 31, p. 105961, 2020.

[36] M. S. Nasr, T. H. Hussain, H. Z. Kubba, and A. A. Shubbar, "Influence of using high volume fraction of silica fume on mechanical and durability properties of cement mortar," Journal of Engineering Science and Technology, vol. 15, no. 4, pp. 2492-2506, 2020.

[37] M. Abed, M. Nasr, and Z. Hasan, "Effect of silica fume/binder ratio on compressive strength development of reactive powder concrete under two curing systems," in MATEC Web of Conferences, 2018, vol. 162, p. 02022.

[38] T. H. Hussain, M. S. Nasr, and H. J. Salman, "Effect of elevated temperature on degradation behavior of reactive powder concrete made with rubber tire wastes as an aggregate replacement," ARPN Journal of Engineering and Applied Sciences, vol. 14, no. 3, pp. 775-780, 2019.

[39] M. S. Nasr, S. A. Salih, and M. S. Hassan, "Some Durability Characteristics of Micro Silica and Nano Silica Contained Concrete," Journal of Babylon University/Engineering Sciences, vol. 24, no. 4, pp. 980-990, 2016.

[40] M. S. Hassan, S. A. Salih, and M. S. Nasr, "Pozzolanic Activity and Compressive Strength of Concrete Incorporated nano/micro Silica," Engineering and Technology Journal, vol. 34, no. 3 Part (A) Engineering, pp. 483-496, 2016.

[41] M. S. Nasr, Z. A. Hasan, and M. K. Abed, "Mechanical Properties of Cement Mortar Made with Black Tea Waste Ash as a Partial Replacement of Cement," Engineering and Technology Journal, vol. 37, Part C, no. 1, pp. 45-49, 2019.

[42] A. A. Shubbar, A. Al-Shaer, R. S. AlKizwini, K. Hashim, H. Al Hawesah, and M. Sadique, "Investigating the influence of cement replacement by high volume of GGBS and PFA on the mechanical performance of cement mortar," in IOP Conference Series: Materials Science and Engineering, 2019, vol. 584, no. 1, p. 12022.

[43] A. A. Shubbar, H. Jafer, A. Dulaimi, K. Hashim, W. Atherton, and M. Sadique, "The development of a low carbon binder produced from the ternary blending of cement, ground granulated blast furnace slag and high calcium fly ash: an experimental and statistical approach," Construction and Building Materials, vol. 187, pp. 1051-1060, 2018.

[44] A. A. F. Shubbar, H. M. Jafer, A. F. D. Dulaimi, W. Atherton, and A. Al-Rifaie, "The Development of a Low Carbon Cementitious Material Produced from Cement, Ground Granulated Blast Furnace Slag and High Calcium Fly Ash," International Journal of Civil, Environmental, Structural, Construction and Architectural Engineering, vol. 11, no. 7, pp. 905-908, 2017.

[45] A. A. Shubbar, D. Al-Jumeily, A. J. Aljaaf, M. Alyafei, M. Sadique, and J. Mustafina, "Investigating the Mechanical and Durability Performance of Cement Mortar Incorporated Modified Fly Ash and Ground Granulated Blast Furnace Slag as Cement Replacement Materials," in 2019 12th International Conference on Developments in eSystems Engineering (DeSE), 2019, pp. 434-439.

[46] I. H. Nayel, S. K. Burhan, and M. S. Nasr, "Characterisation of prepared rice husk ash and its effects on strength development in recycled aggregate concrete," in IOP Conference Series: Materials Science and Engineering, 2018, vol. 433, no. 1, p. 12009.

[47] D. A. J. Hussain, "The Fields of Applying the Recycled and Used Oils by the Internal Combustion Engines for Purposes of Protecting the Environment against Pollutions," Journal of Advanced Research in Dynamical and Control Systems, vol. 12, no. 01-Special Issue, pp. 698-706, 2020.

[48] M. S. Nasr, A. A. Shubbar, Z.-A. R. Abed, and M. S. Ibrahim, "Properties of eco-friendly cement mortar contained recycled materials from different sources," Journal of Building Engineering, vol. 31, p. $101444,2020$.

[49] I. H. Nayel, M. S. Nasr, and S. Q. Abdulridha, "Impact of elevated temperature on the mechanical properties of cement mortar reinforced with rope waste fibres," in IOP Conference Series: Materials Science and Engineering, 2020, vol. 671, no. 1, p. 12080.

[50] I. M. Ali, M. S. Nasr, and A. S. Naje, "Enhancement of cured cement using environmental waste: Particleboards incorporating nano slag," Open Engineering, vol. 10, no. 1, pp. 273-281, 2020.

[51] I. M. Ali, A. S. Naje, and M. S. Nasr, "Eco-Friendly Chopped Tire Rubber as Reinforcements in Fly 
Ash Based Geopolymer Concrete," Global NEST Journal, vol. 22, 2020.

[52] Z. A. Hasan, M. K. Abed, and M. S. Nasr, "Studying the Mechanical Properties of Mortar Containing Different Waste Materials as a Partial Replacement for Aggregate," International Review of Civil Engineering (IRECE), vol. 10, no. 3, p. 155, May 2019.

[53] A. A. Shubbar, M. Sadique, M. S. Nasr, Z. S. Al-Khafaji, and K. S. Hashim, "The impact of grinding time on properties of cement mortar incorporated high volume waste paper sludge ash," Karbala International Journal of Modern Science, vol. 6, no. 4, 2020.

[54] H. Al Hawesah, A. Shubbar, and R. L. Al Mufti, "Non-destructive assessment of early age mortar containing stainless steel powder," in Proceedings of the LJMU 17th Annual International Conference on: Asphalt, Pavement Engineering and Infrastructure, 2018.

[55] M. Abdulredha, A. Abdulridha, A. A. Shubbar, R. Alkhaddar, P. Kot, and D. Jordan, "Estimating municipal solid waste generation from service processions during the Ashura religious event," in IOP Conference Series: Materials Science and Engineering, 2020, vol. 671, no. 1, p. 12075.

[56] H. K. Shanbara, A. Shubbar, F. Ruddock, and W. Atherton, "Characterizing the Rutting Behaviour of Reinforced Cold Mix Asphalt with Natural and Synthetic Fibres Using Finite Element Analysis," in Advances in Structural Engineering and Rehabilitation, Springer, 2020, pp. 221-227.

[57] M. S. Nasr, T. H. Hussain, and W. N. Najim, "Properties of cement mortar containing biomass bottom ash and sanitary ceramic wastes as a partial replacement of cement," International Journal of Civil Engineering and Technology, vol. 9, no. 10, pp. 153-165, 2018.

[58] A. A. F. Shubbar, H. Alwan, E. Y. Phur, J. McLoughlin, and A. Al-khaykan, "Studying the Structural Behaviour of RC Beams with Circular Openings of Different Sizes and Locations Using FE Method," International Journal of Civil, Environmental, Structural, Construction and Architectural Engineering, vol. 11, no. 7, pp. 849-852, 2017.

[59] F. S. Abdulraheem, Z. S. Al-Khafaji, K. S. Hashim, M. Muradov, P. Kot, and A. A. Shubbar, "Natural filtration unit for removal of heavy metals from water," in IOP Conference Series: Materials Science and Engineering, 2020, vol. 888, no. 1, p. 12034. 